
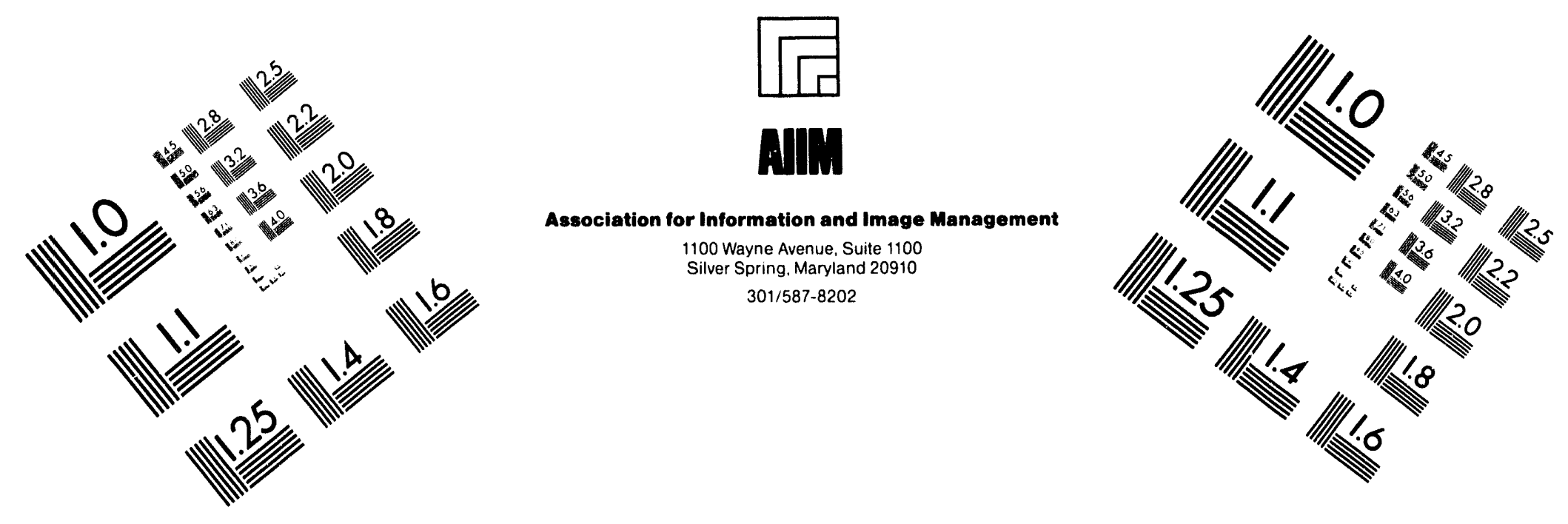

\title{
Centimeter
}

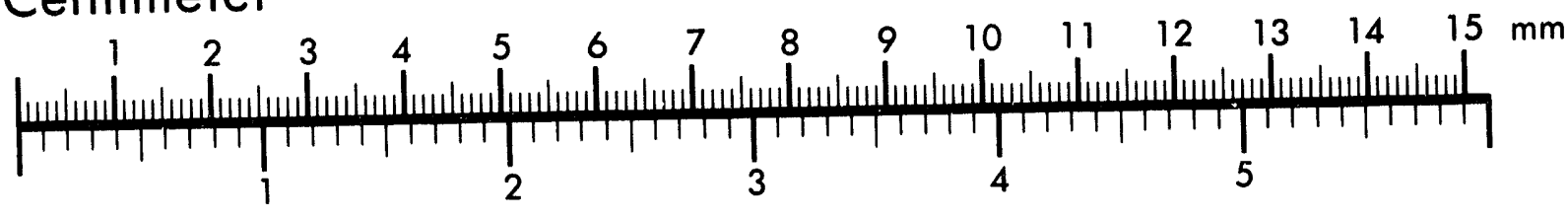
Inches
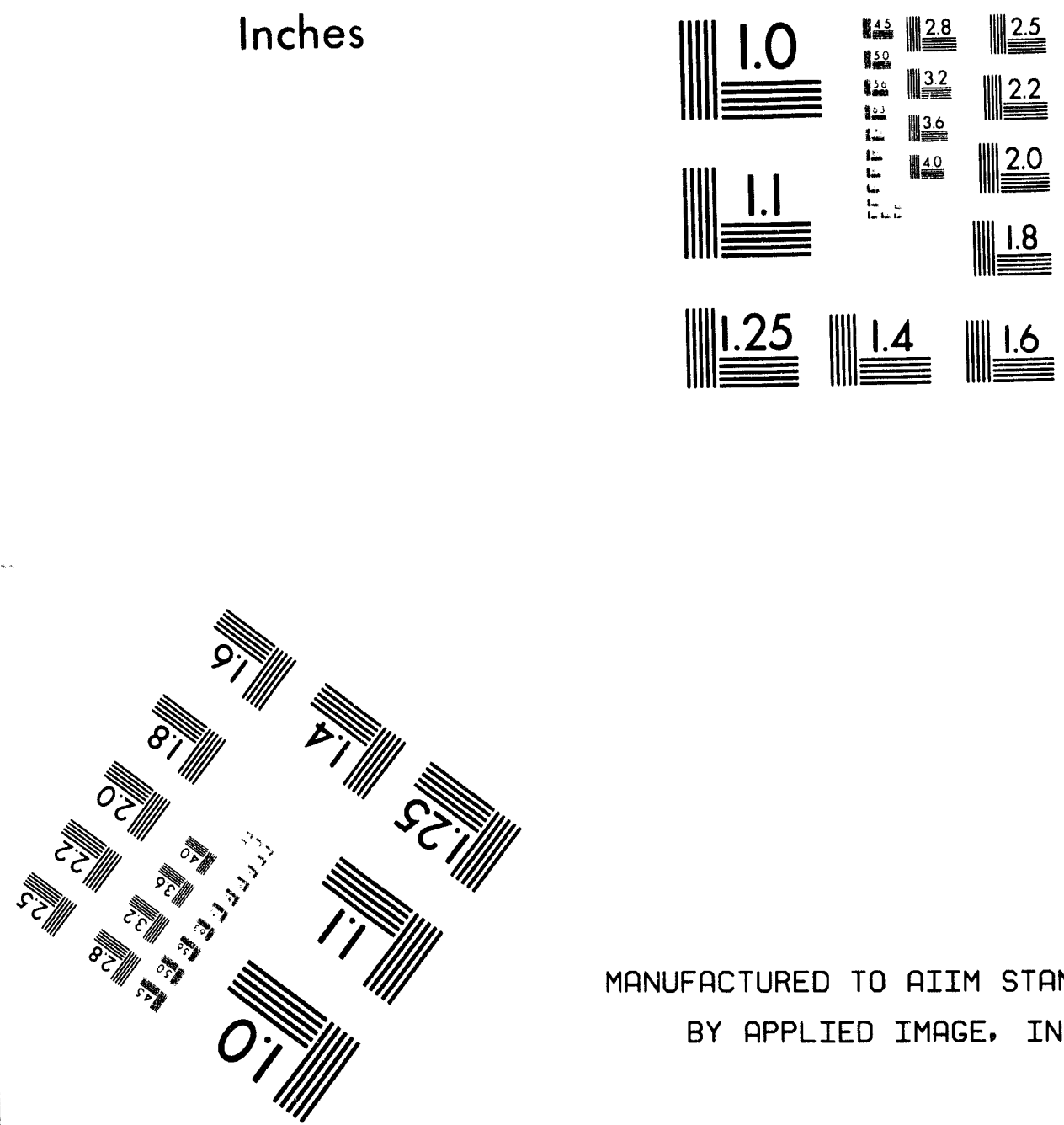

MANUFACTURED TO AIIM STANDARDS

BY APPLIED IMAGE. INC.

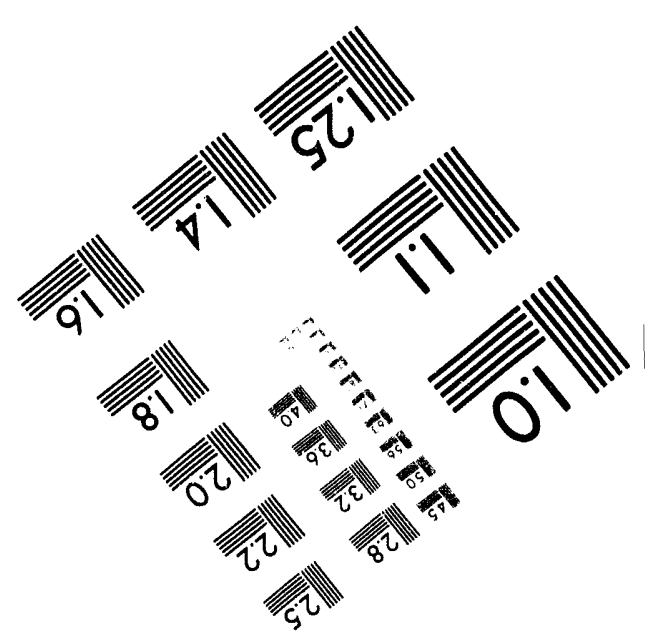



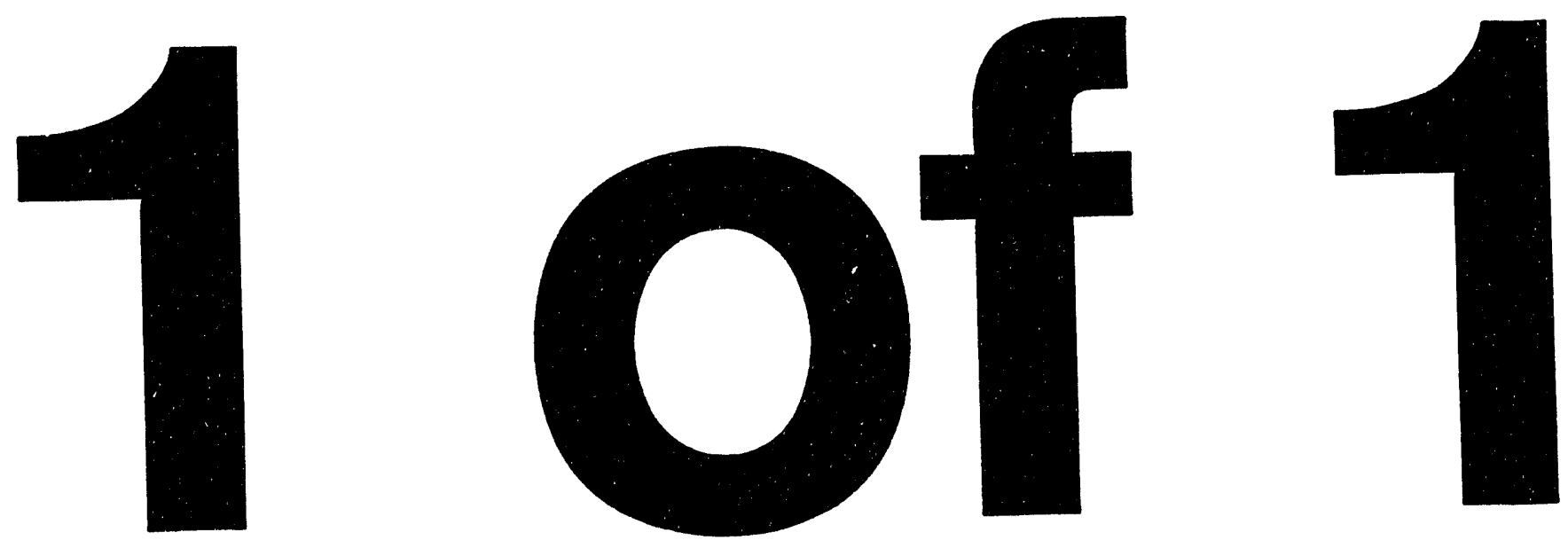


\section{ASSESSMENT OF URANIUM, PLUTONIOUM, AND NP-237 CONTENT OF HIGH LEVEL LIQUID WASTE ON E-AREA VAULT PACKAGE LIMITS}

by

Clemmons, J.S.

Westinghouse Savannah River Company

Savannah River Site

Aiken, South Carolina 29808

A document prepared for N/A at N/A from NA.

This paper was prepared in connection with work done under the above contract number with the U. S. Department of Energy. By acceptance of this paper, the publisher and/or recipient acknowledges the U. S. Government's right to retain a nonexclusive, royalty-free license in and to any copyright covering this paper, along with the right to reproduce and to authorize others to reproduce all or part of the copyrighted paper. 
DISCLAIMER

This report was prepared as an account of work sponsored by an agency of the United States Governmeat. Neither the Uaited States Governmeat nor any ageacy thereof, nor any of their employees, makes any warranty, express or implied, or assumes any legal liability or responsibility for the accuracy. completeness, or usefulaess of any information, apparatus, product, or process disclosed, or represents that its use would not infringe privately owned rights. Reference berein to any specific commercial product, process, or service by trade name. irademark. manufacturer, or otherwise does not necessarily constitute or imply its endorsement, recommendation, or favoring by the United States Government or any ageacy thereof. The views, and opinions of authors expressed berein do not necessarily state or reflect those of the United States Government or any agency ihereof.

This report has beea reproduced directly from the best available copy.

Available to DOE and DOE contractors from the Office of Scieatific and Technical Information. P. O. Box 62, Oak Ridge. TN 37831: prices available from (615) $576-8401$.

Available to the public from the National Techaical Information Service. U. S. Deparmeat of Commerce. S285 Port Royal Rd.. Springfield. VA 22161 
HIGH LEVEL WASTE ENGINEERING HIGH LEVEL ENGINEERING SUPPORT

ASSESSMENT OF URANIUM, PLUTONIUM AND NP-237 CONTENT OF HIGH LEVEL LIQUID WASTE ON E-AREA VAULT PACKAGE LIMITS

BY

J. S. CLEMMONS

ISSUED: June 8, 1994

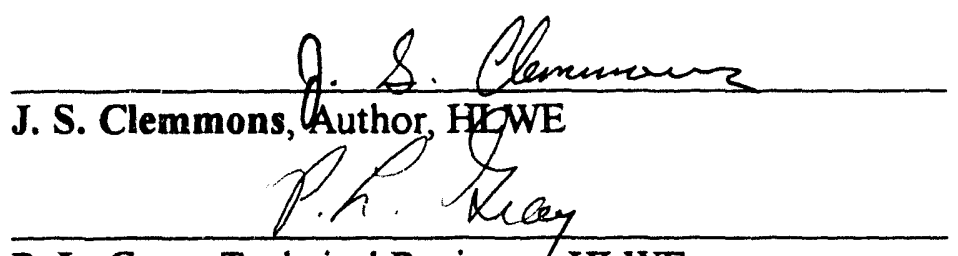

P. L. Gray, Technical Reviewer, HLWE

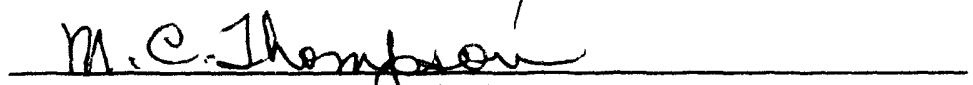

M. C. Thompson, Technical Reviewer, SRTC

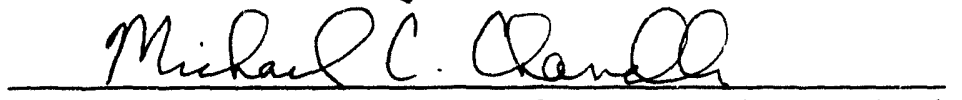

M. C. Chandler, Manager HLWE Waste Characterization

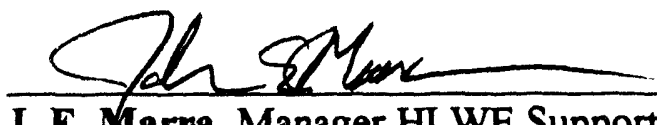

J. E. Marka, Manager HLWE Support U. Sickert for

T. M. Monahon, Manager HLWE (Approved)
WSRC-TR-94- 227

REVISION: 0

KEYWORDS:

Supernate

Uranium

Plutonium

Np-237

E-Area Vaults

RETENTION:

Permanent

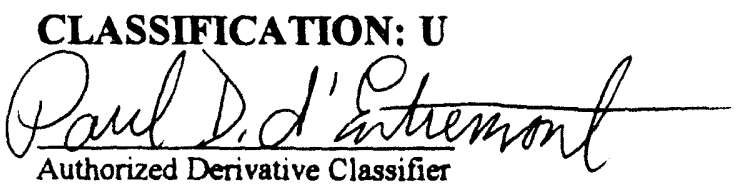

Date: $6 / 8 / 94$

Date: $6 / 8 / 94$

Date: $6 / 13 / 94$

Date: $6 / 15 / 94$

Date: $6 / 15 / 94$

Date: $6 / 17 / 94$ 
O

Technical Report WSRC-TR-94-227, Rev. 0, "Assessment of Uranium, Plutonium and Np-237 Content of High Level Liquid Waste on E-Area Vault Package Limits (U)", June 8, 1994

T. M. Monahon, 703-H

V. G. Dickert, 703-H

J. E. Marra, 703-H

M. C. Chandler, 703-H

M. C. Thompson, 773-A

P. L. Gray, 703-H

C. E. Bess, 703-H

G. K. Georgeton, 703-H

P. D. d'Entremont, 703-H

D. F. Brown, 703-H

M. E. Jamison, 703-H

Central Files, 703-A

HLWE Files, 703-H

(File Code 1.2.1) 
WSRC-TR-94- 2227

Rev. 0

Page 2 of 16

\section{INTRODUCTION}

The purpose of this report is to assess the waste tank inventory of uranium, plutonium and Np237 to determine any potential impacts on waste certification for the E-Area vaults (EAV). Procedure WAC 3.10, Rev. 1, of the 1S Manual imposes administrative control limits for radioactive material in waste packages sent to the EAV. Waste tank supernate contains trace amounts of $\mathrm{U}, \mathrm{Pu}$, and $\mathrm{Np}$. Thus any material contaminated with supernate and placed in a B25 waste package may contain one or more of these elements' radioactive isotopes. This report uses material inventory data, solubility data and tank volumes to determine the potential for waste packages, contaminated with waste tank supernate, to exceed the administrative control limits of procedure WAC 3.10, Rev. 1, for U-233, U-234, U-235, U-236, U-238, Np237, Pu-238, Pu-239, Pu-240, Pu-241, and Pu-242.

\section{SUMMARY}

It is extremely unlikely that waste packages contaminated with waste tank supernate will exceed the Low Activity Waste Vault (LAWV) limits for the isotopes of uranium and plutonium. For many isotopes the volume of supernate required to reach the limit is in excess of the B-25 waste package volume. In addition, all but five tanks were shown to be bound by the Cs-137 content. This means that the waste package limit for Cs-137 would be reached before the limit for the subject actinides.

For the tanks not bound by Cs-137, actual sample concentrations were substituted for bounding solubility limits when available. The volume of supernate to reach the limit increased with the actual sample concentrations indicating that the calculation method was conservative. Due to the limited sample data and solubility data for Np-237, similar demonstrations were not performed for this isotope.

\section{DISCUSSION}

Uranium, plutonium and neptunium are only slightly soluble in alkaline waste. Therefore when acidic canyon waste streams are neutralized, prior to receipt in the tank farm, the bulk of these elements precipitate and settle with other alkaline insoluble elements in the sludge. The uranium, plutonium and $\mathrm{Np}-237$ content in tanks containing sludge has been well characterized [1], both from a total mass and isotopic perspective. Thus it is possible to determine the average isotopic content for $\mathrm{Pu}$ and $\mathrm{U}$ in the majority of the waste tanks.

To determine the potential for exceeding the EAV waste package limits, a bounding supernate concentration was calculated for each isotope of concern per tank. Using this concentration it was possible to calculate the required volume of supernate necessary to exceed the package limits. The volume of supernate necessary to exceed the waste package limits was then 
compared to the volume of supernate necessary to exceed the Cs-137 limit. This indicates whether the particular isotope is bound by the Cs-137 concentration, meaning the Cs-137 package limit would be exceeded prior to exceeding the U, Pu or $\mathrm{Np}-237$ limit.

The EAV administrative control limits for $\mathrm{Np}-237$ and the isotopes of $\mathrm{U}$ and $\mathrm{Pu}$ are reproduced below from Table 2 of procedure WAC 3.10, Rev. 1. The most conservative package limits are those for the Low Activity Waste Vaults (LAWV). These limits will be used as the criteria henceforth in this report. Note that the ILTV Crucibles U-235 limit of 9.3E-6 Ci/Pkge is less than the LAWV limit of 1.1E-4. The ILTV Crucibles vault is specifically designed to handle waste from the Tritium facility and is not designated to receive material contaminated with waste tank supernate.

Table 1. EAV Waste Package Administrative Control Limits for U, Pu and Np-237 [6].

\begin{tabular}{|c|c|c|c|c|c|c|}
\hline Isotope & $\begin{array}{c}\text { LAWV } \\
\text { (Ci/Pkg.) }\end{array}$ & $\begin{array}{c}\text { ILNTV } \\
\text { Combust. } \\
\text { (Ci/Pkg.) }\end{array}$ & $\begin{array}{c}\text { ILNTV } \\
\text { Non-Combust. } \\
\text { (Ci/Pkg.) }\end{array}$ & $\begin{array}{c}\text { LTV } \\
\text { Bulk } \\
\text { (Ci/Pkg.) }\end{array}$ & $\begin{array}{c}\text { ILTV } \\
\text { Crucibles } \\
\text { (Ci/Pkg.) }\end{array}$ & $\begin{array}{l}\text { LLWSB } \\
\text { (Ci/Pkg.) }\end{array}$ \\
\hline $\mathrm{Np}-237$ & $2.2 \mathrm{E}-5$ & $7.8 \mathrm{E}-5$ & $4.7 \mathrm{E}-4$ & $1.1 \mathrm{E}-4$ & $1.6 \mathrm{E}-4$ & $2.3 \mathrm{E}-1$ \\
\hline U-233 & $2.2 \mathrm{E}-5$ & $3.3 \mathrm{E}-5$ & 3.3E-5 & $3.3 \mathrm{E}-5$ & $3.3 \mathrm{E}-5$ & $3.3 \mathrm{E}-5$ \\
\hline U-234 & 7.5E-3 & $7.5 \mathrm{E}-3$ & 2.3E-2 & $7.5 \mathrm{E}-2$ & 7.9E-3 & $2.3 \mathrm{E}-1$ \\
\hline U-235 & $1.1 \mathrm{E}-4$ & $1.1 \mathrm{E}-4$ & 1.1E-4 & $1.1 \mathrm{E}-4$ & $9.3 E-6$ & $1.1 \mathrm{E}-4$ \\
\hline U-236 & $1.4 \mathrm{E}-3$ & 2.3E-3 & $1.8 \mathrm{E}+0$ & $2.3 \mathrm{E}-2$ & $1.8 \mathrm{E}-2$ & $2.3 \mathrm{E}-1$ \\
\hline U-238 & 2.3E-3 & 2.3E-3 & 1.2E-1 & $2.3 \mathrm{E}-2$ & $1.8 \mathrm{E}-2$ & 2.3E-1 \\
\hline Pu-238 & 9.1E-2 & $2.3 \mathrm{E}-1$ & $1.8 \mathrm{E}+0$ & 2.3E-1 & $1.8 \mathrm{E}-1$ & $2.3 \mathrm{E}-1$ \\
\hline Pu-239 & $9.1 \mathrm{E}-2$ & 2.3E-1 & $1.8 \mathrm{E}+0$ & $2.3 \mathrm{E}-1$ & $1.8 \mathrm{E}-1$ & $2.3 \mathrm{E}-1$ \\
\hline $\mathrm{Pu}-240$ & $9.1 \mathrm{E}-2$ & $2.3 \mathrm{E}-1$ & $1.8 \mathrm{E}+0$ & $2.3 \mathrm{E}-1$ & $1.8 \mathrm{E}-1$ & 2.3E-1 \\
\hline $\mathrm{Pu}-241$ & $1.1 \mathrm{E}+0$ & 2.7E+0 & $2.2 \mathrm{E}+1$ & $2.7 \mathrm{E}+0$ & $2.2 \mathrm{E}+0$ & $2.7 \mathrm{E}+0$ \\
\hline $\mathrm{Pu}-242$ & $9.1 \mathrm{E}-2$ & 2.3E-1 & $1.8 \mathrm{E}+0$ & $2.3 \mathrm{E}-1$ & $1.8 \mathrm{E}-1$ & 2.3E-1 \\
\hline
\end{tabular}

\section{Calculation Results}

Calculation results for $\mathrm{U}, \mathrm{Pu}$ and $\mathrm{Np}-237$ are discussed in the following sections. Each section describes the calculation method in sufficient detail for an independent reviewer to duplicate. Table 2 below, provides the specific activities for the isotopes addressed. 
Table 2. Specific Activities of Np-237 and $U$ and Pu Isotopes of Interest [7]

\begin{tabular}{|c|c|}
\hline Isotope & $\begin{array}{l}\text { Specific Activity } \\
\text { (Curies/gram) }\end{array}$ \\
\hline$\overline{\mathrm{Np}-237}$ & $7.049 \mathrm{E}-4$ \\
\hline U-233 & $9.680 \mathrm{E}-3$ \\
\hline U-234 & $6.248 \mathrm{E}-3$ \\
\hline U-235 & $2.161 \mathrm{E}-6$ \\
\hline U-236 & $6.469 \mathrm{E}-5$ \\
\hline U-238 & $3.362 \mathrm{E}-7$ \\
\hline $\mathrm{Pu}-238$ & $1.712 \mathrm{E}+1$ \\
\hline Pu-239 & $6.216 \mathrm{E}-2$ \\
\hline $\mathrm{Pu}-240$ & $2.279 \mathrm{E}-1$ \\
\hline $\mathrm{Pu}-241$ & $1.030 \mathrm{E}+2$ \\
\hline Pu-242 & $3.818 \mathrm{E}-3$ \\
\hline
\end{tabular}

\section{Uranium}

Uranium tank inventory values are listed in Appendix 1, Table 1. Beside the mass value for each isotope is the isotopic wt. \% of the tank total $U$ inventory. In Appendix 1, Table 2 are the required volumes of supernate in each tank to reach the LAWV package limit for each isotope. This volume of supernate was calculated with the following equation and is referred to throughout the remainder of the report as the limiting volume:

Volume of supernate for U-23X LAWV Limit:

$=\frac{\mathrm{U}-23 \times \text { LAWV Limit (Ci/Package) }}{\text { T-23X }(\mathrm{g})} \times \frac{20.0 \mathrm{mg} U}{\text { liter }} \times \frac{1 \mathrm{~g}}{1000 \mathrm{mg}} \times \frac{3.7851}{\text { gallon }} \times \operatorname{Sp~Activity~U-23X~} \frac{(\mathrm{Ci})}{(\mathrm{g})}$
$=\quad$ Gallon of U-23X per waste package.

Where:

$\mathrm{U}-23 \mathrm{X}$ is the isotope of uranium being considered.

$20.0 \mathrm{mg} / \mathrm{l}$ is the solubility limit of $U$ in alkaline waste[10]

The uranium isotopes' limiting volumes are compared to the Cs-137 limiting volume for each tank in Appendix 1, Table 2. The Cs-137 limiting volumes were determined from the most recent sample data available [9] and are presented in Appendix 4, Table 1. If the limiting uranium volume is greater than the limiting Cs- 137 volume, then Cs-137 bounds the uranium isotope. If the reverse is true, then the uranium isotope is not bound and is so designated. No 
WSRC-TR-94- 227

Rev. 0

Page 5 of 16

Cs-137 sample data is available for tank 3F, therefore a comparison is not made. Since the fill history and uranium isotopic distribution for tank $3 \mathrm{~F}$ is similar to that of tanks $1 \mathrm{~F}$ and $2 \mathrm{~F}$, similar results are expected. The LAWV waste package limit for Cs-137 is $0.76 \mathrm{Ci}$ [6]. Below is a summary table of the uranium calculations for all tanks evaluated.

Table 3. Uranium Characteristics Summary

\begin{tabular}{|c|c|c|c|c|c|c|}
\hline No. & Parameter & $\underline{\mathrm{U}-233}$ & $\underline{\mathbf{U}-234}$ & $\underline{\mathrm{U}-235}$ & $\underline{\mathrm{U}-236}$ & U-238 \\
\hline 1 & Minimum Limiting Volume (gals) & 1 & 1050 & 952 & 793 & 90500 \\
\hline 2 & Average Limiting Volume (gals) & 436 & 521000 & 135000 & 603000 & 90900 \\
\hline 3 & \# Tanks not bound by Cs-137 & 2 & 0 & 0 & 0 & \\
\hline 4 & Min Isotopic Wt. \% Evaluated & 0.00 & 0.00 & 0.17 & 0.00 & 10.4 \\
\hline 5 & Max Isotopic Wt. \% Evaluated & 3.58 & 1.52 & 70.65 & 36.05 & 99.8 \\
\hline
\end{tabular}

From the calculations, only two tanks have a uranium isotope that is not bound by Cs-137. These two tanks are $15 \mathrm{H}$ and $21 \mathrm{H}$ and for both tanks the isotope is $\mathrm{U}-233$. Tank $15 \mathrm{H}$ has the highest U-233 isotopic wt. \% in the tank farm and the fourth lowest Cs-137 concentration. However a waste package must contain no less than one gallon of tank $15 \mathrm{H}$ supernate to reach the limit. Supernate sampling from the slurrying and transfer of $15 \mathrm{H}$ sludge to tank $42 \mathrm{H}$ demonstrates the conservative margin of using the bounding $U$ concentration of $20.0 \mathrm{mg} / \mathrm{l}$. The $U$ concentration in the decanted supernate from the transfer was $1.2 \mathrm{mg} / \mathrm{l}$ [8]. Substituting this value in place of $20.0 \mathrm{mg} / \mathrm{l}$, yields an increase in the limiting volume to 14 gallons.

For tanks such as $15 \mathrm{H}$, where sample data does exist, more accurate limiting volumes can be calculated. There is not much guidance on the amount of supernate that may end up in a waste package, even though the liquid content per package is limited [6]. It does not seem likely that 14 gallons of liquid waste would be put in a waste package. In this report, the only volume of supernate that is discounted is that in excess of the waste package volume.

Similar to tank $15 \mathrm{H}$, tank $21 \mathrm{H}$ also has a low Cs-137 concentration. Of the tanks evaluated, tank $21 \mathrm{H}$ had the second lowest Cs-137 concentration which gave a limiting volume of 73 gallons. The U-233 limiting volume of 11 gallons is thus not bounded. The level of supernate in tank $21 \mathrm{H}$ is 34.7 inches which corresponds to a volume of $123 \mathrm{kgal}$ (3540 gal/in). The total mass of U-233 in tank $21 \mathrm{H}$ is 18 grams giving a concentration of $0.04 \mathrm{mg} / 1$. Substituting this concentration in place of the U-233 isotopic weight fraction times $20.0 \mathrm{mg} / \mathrm{l}$ gives a limiting volume of 15 gallons. Not much of an increase, but still conservative since the majority of the $U$ inventory will be present in the sludge. The possibility of placing more than 15 gallons of tank $21 \mathrm{H}$ supernate in a waste package is not addressed.

The limiting volumes for U-234, U-235, U-236 and U-238 are all bound by Cs-137 for each tank. In addition, the minimum limiting volumes for these isotopes are in excess of the B-25 package volume of 673 gallons $\left(90 \mathrm{ft}^{3}\right.$ at $\left.7.48052 \mathrm{gal} / \mathrm{ft}^{3}\right)$. On an overall mass basis, the average limiting volume for all the uranium isotopes is over 400 gallons. This average was 
determined based on the isotopics of the entire tank farm uranium inventory. This average value represents the most likely cases as waste processing begins and waste from different tanks is combined and mixed.

\section{Plutonium}

Plutonium tank inventory values are listed in Appendix 2, Table 1. The format is identical to that used for uranium. The volume of supernate necessary to reach the LAWV package limit for each isotope is calculated similar to that for uranium except that the solubility limit of $\mathrm{Pu}$ in alkaline waste is $1.68 \mathrm{mg} / \mathrm{l}$ [2]. Below is a summary of the plutonium calculations for all tanks evaluated.

\section{Table 4. Plutonium Characteristics Summary}

\begin{tabular}{|c|c|c|c|c|c|c|}
\hline No. & Parameter & Pu-238 & Pu-239 & $\underline{\mathrm{Pu}-240}$ & $\underline{\mathrm{Pu}-241}$ & $\underline{\mathrm{Pu}-242}$ \\
\hline 1 & Minimum Limiting Volume (gals) & 0.84 & 245 & 521 & 39 & 225865 \\
\hline 2 & Average Limiting Volume (gals) & 5.8 & 312 & 687 & 92 & 414035 \\
\hline 3 & \# Tanks not bound by Cs- 137 & 2 & 1 & 1 & 1 & 0 \\
\hline 4 & Min Isotopic Wt. \% Evaluated & 0.00 & 0.00 & 0.00 & 0.00 & 0.00 \\
\hline 5 & Max Isotopic Wt. \% Evaluated & 100.00 & 94.10 & 12.05 & 4.25 & 1.66 \\
\hline
\end{tabular}

From the calculations, only three tanks have a plutonium isotope that is not bound by Cs-137. These three tanks are 15H (Pu-238), 17F (Pu-239, Pu-240, Pu-241) and 21H (Pu-238). Recall that tanks $15 \mathrm{H}$ and $21 \mathrm{H}$ were the only tanks with an unbounded $\mathrm{U}$ isotope. Tanks $15 \mathrm{H}, 17 \mathrm{~F}$ and $21 \mathrm{H}$ have the fourth, first and second lowest Cs-137 concentration of all tanks evaluated.

The Cs-137 limiting volume for tank $15 \mathrm{H}$ is 26 gallons which does not bound the Pu-238 limiting volume of 6 gallons. As indicated in the solubility limits, $\mathrm{Pu}$ is much less soluble in alkaline waste than $\mathrm{U}$. The $\mathrm{Pu}$ concentration in the decanted supernate from tank $15 \mathrm{H}$ to $42 \mathrm{H}$ sludge transfers was 8.2 grams in $642 \mathrm{kgal}$ of supernate [8] which gives a concentration of $0.0034 \mathrm{mg} /$. Substituting this concentration in place of the bounding concentration of 1.68 $\mathrm{mg} / \mathrm{l}$ gives a limiting volume of 2900 gallons. This is in excess of the B-25 package volume and also in excess of the Cs-137 linsiting volume. Though unnecessary, similar results could be achieved with the other $\mathrm{Pu}$ isotopes in tank $15 \mathrm{H}$.

Three isotopes in tank 17F are not bound by the Cs-137 content, Pu-239, Pu-240, and Pu-241. The limiting volumes for these isotopes is 249,942 , and 551 gallons respectively, while the limiting volume for $\mathrm{Cs}-137$ is 5710 gallons. No attempt is made to reduce the bounding estimates to more accurate values. The possibility of putting more than 249 gallons of tank $17 \mathrm{~F}$ supernate in a waste package is not addressed.

Tank $21 \mathrm{H}$ has a Pu-238 limiting volume of 1.13 gallons which is not bound by the Cs-137 limiting volume of 73.1 gallons. The level of supernate in tank $21 \mathrm{H}$ is 34.7 inches which 
corresponds to a volume of $123 \mathrm{kgal}$ (3540 gal/in). The total mass of $\mathrm{Pu}-238$ in tank $21 \mathrm{H}$ is 59 grams giving a concentration of $0.13 \mathrm{mg} / \mathrm{l}$. Substituting this concentration in place of the $\mathrm{Pu}-238$ isotopic weight fraction times $1.68 \mathrm{mg} / 1$ gives a limiting volume of 11 gallons. This assumes that the entire $\mathrm{Pu}$ inventory is distributed throughout the entire waste volume, which is conservative since $\mathrm{Pu}$ is predominantly in the sludge. The Pu-238 is still not bound by $\mathrm{Cs}-$ 137 but the limiting volume was increased by almost a factor of ten. The possibility of placing more than 11 gallons of tank $21 \mathrm{H}$ supernate in a waste package is not addressed.

The limiting volume for $\mathrm{Pu}-242$ is bound by $\mathrm{Cs}-137$ for each tank and the minimum limiting volume for Pu-242 is in excess of the B-25 package volume. Therefore it is not possible that material contaminated with supernate will ever exceed the LAWV package limits for Pu-242. The minimum limiting volumes for the remaining Pu isotopes are not in excess of the B-25 volume however, it does not seem likely that quantities of supernate that large would be put in a B-25. As with the uranium isotopes, the average limiting volumes are in excess of the minimum.

\section{$\mathbf{N p - 2 3 7}$}

Np-237 tank inventory values are listed in Appendix 3, Table 1. The format is similar to that for $\mathrm{U}$ and $\mathrm{Pu}$. The volume of supernate necessary to reach the LAWV limit is calculated somewhat different. Solubility limits for Np are not available. Therefore the Np-237 tank inventory was distributed throughout the entire tank waste volume to determine the concentration and thus the limiting volumes. This is considered to be conservative since the majority of $\mathrm{Np}$ will be in the sludge. Below is a summary of the $\mathrm{Np}-237$ calculations for all tanks evaluated.

\section{Table 5. Np-237 Characteristics Summary}

\begin{tabular}{clr} 
No. & \multicolumn{1}{c}{ Parameter } & Np-237 \\
\hline 1 & Minimum Limiting Volume (gals) & 0.18 \\
2 & Average Limiting Volume (gals) & 5.6 \\
3 & \# Tanks not bound by Cs-137 & 4
\end{tabular}

Four tanks that contain Np-237 are not bound by Cs-137 per the calculation method used in this report. These four tanks are $8 \mathrm{~F}, 12 \mathrm{H}, 15 \mathrm{H}$ and $21 \mathrm{H}$. Since documented reliable Np-237 sample data or solubility data is not available, more accurate estimates of the limiting volumes for these tanks cannot be performed. The limiting volumes for each of these tanks in Appendix 3 , Table 2 must be addressed to determine the likelihood of putting that volume of waste tank supernate in a B-25 waste package. One other option is to sample the supernate in these tanks for $\mathrm{Np}-237$. Since Np remains primarily in the sludge after neutralization, distributing the entire tank $\mathrm{Np}$ inventory equally throughout the waste volume is considered to be a conservative approach to estimating the supernate concentration. 
WSRC-TR-94- -227

Rev. 0

Page 8 of 16

\section{CONCLUSION}

Of the 34 tanks evaluated, 5 contained Np-237 and/or isotopes of $\mathrm{U}$ and $\mathrm{Pu}$ whose calculated limiting volumes were not in excess of the $\mathrm{Cs}-137$ limiting volumes as determined from sample data. These tanks are listed below. The remaining tanks not evaluated are predominantly evaporator concentrate receipt tanks. Due to the volume reduction of supernate after evaporation, these tanks will contain higher concentrations of Cs-137. Thus these tanks would not be limiting in this evaluation.

Table 6. Summary of Tanks with Isotopes not Bound by CS-137.

\begin{tabular}{cl} 
Tank & Isotope(s) Not Bound by Cs-137 \\
\hline 8 & $\mathrm{~Np}-237$ \\
12 & $\mathrm{~Np}-237$ \\
15 & $\mathrm{U}-233, \mathrm{Pu}-238, \mathrm{~Np}-237$ \\
17 & $\mathrm{Pu}-239, \mathrm{Pu}-240, \mathrm{Pu}-241$ \\
21 & $\mathrm{U}-233, \mathrm{Pu}-238, \mathrm{~Np}-237$
\end{tabular}

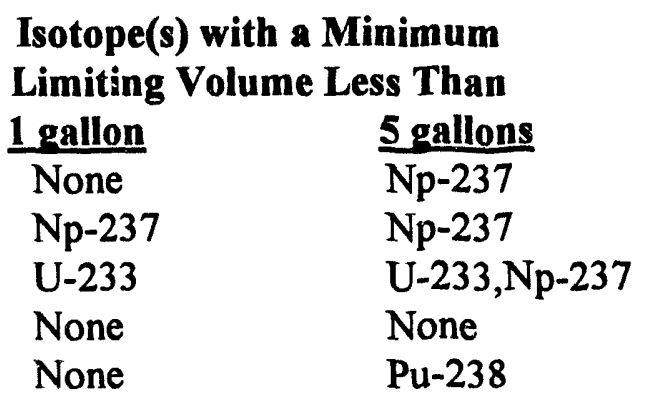

Per the calculation method, only tanks 12 and 15 had an isotope with a limiting volume less than or equal to 1 gallon of supernate and were also not bound by the Cs-137 limiting volume. Actual sample data for tank 15 demonstrated that the actual limiting volume was much higher. Sample data for a similar analysis for tank 12 is currently unavailable, however similar results would be expected (i.e., actual Np-237 supernate concentration should be less than the calculated value of $13.8 \mathrm{mg} / \mathrm{l}$ ).

This report demonstrates by a conservative method, that for the majority of waste tanks, a significant volume of supernate would be required to exceed the administrative control limits for $\mathrm{Np}-237$ and the isotopes of $\mathrm{U}$ and $\mathrm{Pu}$. In addition, most waste tanks were shown to have a Cs-137 limiting volume that would preclude reaching the limiting volume for the actinides evaluated. For the tanks not bound by Cs-137 and where sample data was unavailable to lessen the conservatism, samples can be obtained and analyzed to examine their content further. 
WSRC-TR-94- 227

Rev. 0

Page 9 of 16

\section{REFERENCES}

[1] WSRC-TR-94-191, Revision 0, "Estimated Sludge Inventory for Individual Tanks (U)", May 4, 1994

[2] WSRC-TR-93-056, "Solubility of Plutonium and Uranium in Alkaline Salt Solutions (U)",February 12, 1993

[3] WSRC-TR-93-433, Rev. 0, "Uranium Solubility Studies During Waste Evaporation (U)", August 16, 1993

[4] WSRC-TR-93-578, Rev. 0, "Solubility Of Plutonium In Waste Evaporation (U)", October 22, 1993

[5] WSRC-TR-93-131, "Solubility of Plutonium in Alkaline Salt Solutions (U)", February 26, 1993

[6] 1S Manual, Procedure WAC 3.10, Rev. 1, 5/21/94

[7] DOE'RW-0006, Rev. 7, Integrated Data Base for 1991: U. S. Spent Fuel and Radioactive Waste Inventories, Projections, and Characteristics, October 1991

[8] WER-HLE-930561, Clemmons to Chandler, "Effect of ESP on Waste Tank Sludge U, Pu, Fe and Mn Content (U)", February 10, 1993.

[9] HLW-HLE-94-0328, J. A. Pike to M. C. Chandler, "Radio Nuclide Sample Analysis of Waste Tanks 1-51 (U)", January 24, 1994

[10] WSRC-TR-93-454, "Solubility of Uranium in Alkaline Salt Solutions (U)", March 29, 1994. 
Appendix 1

WSRC-TR-94- 227

Rev. 0

Page 10 of 16

Table 1. Uranium Isotopic Waste Tank Inventory

\begin{tabular}{|c|c|c|c|c|c|c|c|c|c|c|c|}
\hline & Total & & & & & & & & & & \\
\hline & Uranium & U-233 & U-233 & U-234 & U-234 & U-235 & U-235 & U-236 & U-236 & U-238 & U-238 \\
\hline TANK\# & $(\mathrm{Kg})$ & (g) & wt. $\%$ & (g) & wt. \% & (g) & wt. \% & (g) & wt. $\%$ & (q) & wt. \% \\
\hline 1 & 1315 & 0 & 0.00 & 0 & 0.00 & 8167 & 0.62 & 0 & 0.00 & $1.31 \mathrm{E}+06$ & 99.38 \\
\hline 2 & 61 & 0 & 0.00 & 0 & 0.00 & 376 & 0.62 & 0 & 0.00 & $6.02 \mathrm{E}+04$ & 99.38 \\
\hline 3 & 151 & 0 & 0.00 & 0 & 0.00 & 939 & 0.62 & 0 & 0.00 & $1.50 \mathrm{E}+05$ & 99.38 \\
\hline 4 & 9980 & 0 & 0.00 & 0 & 0.00 & 35951 & 0.36 & 0 & 0.00 & $9.94 \mathrm{E}+06$ & 99.64 \\
\hline 5 & 7425 & 0 & 0.00 & 0 & 0.00 & 48448 & 0.65 & 0 & 0.00 & $7.38 \mathrm{E}+06$ & 99.35 \\
\hline 6 & 7425 & 0 & 0.00 & 0 & 0.00 & 30763 & 0.41 & 0 & 0.00 & $7.39 \mathrm{E}+06$ & 99.59 \\
\hline 7 & 27414 & 0 & 0.00 & 0 & 0.00 & 175553 & 0.64 & 0 & 0.00 & $2.72 E+07$ & 99.36 \\
\hline 8 & 20702 & 0 & 0.00 & \begin{tabular}{l|l}
0 \\
\end{tabular} & 0.00 & 69757 & 0.34 & 0 & 0.00 & $2.06 \mathrm{E}+07$ & 99.66 \\
\hline 9 & 88 & 0 & 0.00 & 0 & 0.00 & 546 & 0.62 & 0 & 0.00 & $8.75 E+04$ & 99.38 \\
\hline 10 & 17 & 0 & 0.00 & 0 & 0.00 & 106 & 0.62 & 0 & 0.00 & $1.69 E+04$ & 99.38 \\
\hline 11 & 194 & 211 & 0.11 & 268 & 0.14 & 14631 & 7.56 & 4004 & 2.07 & $1.74 \mathrm{E}+05$ & 90.12 \\
\hline 12 & 2060 & 3955 & 0.19 & 574 & 0.03 & 31211 & 1.51 & 4391 & 0.21 & $2.02 E+06$ & 98.05 \\
\hline 13 & 5533 & 4194 & 0.08 & 917 & 0.02 & 72487 & 1.31 & 9131 & 0.17 & $5.45 \mathrm{E}+06$ & 98.43 \\
\hline 14 & 237 & 39 & 0.02 & 8 & 0.00 & 1920 & 0.81 & 68 & 0.03 & $2.35 \mathrm{E}+05$ & 99.14 \\
\hline 15 & 40 & 1433 & 3.58 & 608 & 1.52 & 28308 & 70.65 & 5547 & 13.84 & $4.17 \mathrm{E}+03$ & 10.42 \\
\hline 17 & 250 & 0 & 0.00 & 0 & 0.00 & 625 & 0.25 & 0 & 0.00 & $2.50 \mathrm{E}+05$ & 99.75 \\
\hline 18 & 464 & 0 & 0.00 & 0 & 0.00 & 1454 & 0.31 & 0 & 0.00 & $4.63 \mathrm{E}+05$ & 99.69 \\
\hline 19 & 55 & 0 & 0.00 & 0 & 0.00 & 94 & 0.17 & 0 & 0.00 & $5.49 \mathrm{E}+04$ & 99.83 \\
\hline 21 & 6 & 18 & 0.28 & 27 & 0.43 & 1091 & 16.97 & 541 & 8.42 & $4.75 \mathrm{E}+03$ & 73.91 \\
\hline 22 & 29 & 111 & 0.38 & 62 & 0.21 & 2734 & 9.28 & 983 & 3.34 & $2.56 \mathrm{E}+04$ & 86.80 \\
\hline 26 & 6024 & 0 & 0.00 & 0 & 0.00 & 10241 & 0.17 & 0 & 0.00 & $6.01 \mathrm{E}+06$ & 99.83 \\
\hline 30 & 0 & 0 & 0.00 & 3 & 1.21 & 150 & 62.30 & 52 & 21.64 & $3.58 \mathrm{E}+01$ & 14.85 \\
\hline 32 & 84 & 0 & 0.00 & 444 & 0.53 & 18362 & 21.89 & 9622 & 11.47 & $5.54 \mathrm{E}+04$ & 66.10 \\
\hline 33 & 25682 & 0 & 0.00 & 0 & 0.00 & 43659 & 0.17 & 0 & 0.00 & $2.56 \mathrm{E}+07$ & 99.83 \\
\hline 34 & 24003 & 0 & 0.00 & 0 & 0.00 & 52761 & 0.22 & 0 & 0.00 & $2.40 \mathrm{E}+07$ & 99.78 \\
\hline 35 & 118 & 0 & 0.00 & 435 & 0.37 & 21852 & 18.58 & 12404 & 10.55 & $8.29 E+04$ & 70.50 \\
\hline 36 & 0 & 0 & 0.00 & 1 & 0.48 & 65 & 26.81 & 40 & 16.32 & $1.37 \mathrm{E}+02$ & 56.39 \\
\hline 39 & 48 & 0 & 0.00 & 553 & 1.15 & 23438 & 48.81 & 12607 & 26.26 & $1.14 \mathrm{E}+04$ & 23.78 \\
\hline 40 & 4820 & 148 & 0.00 & 82 & 0.00 & 18611 & 0.39 & 1308 & 0.03 & $4.80 \mathrm{E}+06$ & 99.58 \\
\hline 41 & 0 & 0 & 0.00 & 2 & 1.30 & 66 & 43.51 & 55 & 36.05 & $2.91 E+01$ & 19.14 \\
\hline 42 & 3444 & 777 & 0.02 & 443 & 0.01 & 33336 & 0.97 & 5720 & 0.17 & $3.40 E+06$ & 98.83 \\
\hline 43 & 28 & 0 & 0.00 & 335 & 1.18 & 13713 & 48.44 & 7524 & 26.58 & $6.74 \mathrm{E}+03$ & 23.80 \\
\hline 47 & 4514 & 0 & 0.00 & 0 & 0.00 & 8629 & \begin{tabular}{l|l}
0.19 \\
\end{tabular} & 0 & 0.00 & $4.51 E+06$ & 99.81 \\
\hline 51 & 6863 & 79 & 0.00 & 78 & 0.00 & 24640 & 0.36 & 1448 & 0.02 & $6.84 \mathrm{E}+06$ & 99.62 \\
\hline Total Mass & 159077 & 10965 & & 4841 & & 794681 & & 75444 & & $1.58 E+08$ & \\
\hline \multicolumn{12}{|l|}{ Isotopics } \\
\hline Minimum & & & 0.00 & & 0.00 & & 0.17 & & 0.00 & & 10.42 \\
\hline Average & & & 0.01 & & 0.00 & & 0.50 & & 0.05 & & 99.44 \\
\hline Maximum & & & 3.58 & & 1.52 & & 70.65 & & 36.05 & & 99.83 \\
\hline
\end{tabular}


WSRC-TR-94 20

Rev. 0

Appendix 1

Page 11 of 16

Table 2. Comparison of U Limiting Volumes to Cs-137 Limiting Volumes

\begin{tabular}{|c|c|c|c|c|c|c|c|}
\hline & Volume of & Volume of & Volume of & Volume of & Volume of & Volume of & \\
\hline & Supernate & Supernate & Supernate & Supernate & Supernate & Supernate & \\
\hline & for Cs-137 & for U-233 & for U-234 & for U-235 & for $U-236$ & for U-238 & \\
\hline & Limit & Limit & Limit & Limit & Limit & Limit & Tanks with U not \\
\hline TANK\# & (gallons) & (gallons) & (agllons) & (gallons) & (gallons) & (gallons) & bound by Cs-137 \\
\hline$!$ & $4.13 \mathrm{E}-02$ & & & $1.08 \mathrm{E}+05$ & & $9.09 \mathrm{E}+04$ & \\
\hline 2 & $1.34 \mathrm{E}-01$ & & & $1.08 \mathrm{E}+05$ & & $9.09 \mathrm{E}+04$ & \\
\hline 3 & No sample & & & $1.08 \mathrm{E}+05$ & & $9.09 E+04$ & Not Bound by Cs-137 \\
\hline 4 & 6.97E-02 & & & $1.87 \mathrm{E}+05$ & & $9.07 \mathrm{E}+04$ & \\
\hline 5 & $1.94 \mathrm{E}-02$ & & & $1.03 \mathrm{E}+05$ & & $9.10 \mathrm{E}+04$ & \\
\hline 6 & $1.11 \mathrm{E}-01$ & & & $1.62 \mathrm{E}+05$ & & $9.07 \mathrm{E}+04$ & \\
\hline 7 & $2.56 \mathrm{E}-01$ & & & $1.05 E+05$ & & $9.10 \mathrm{E}+04$ & \\
\hline 8 & $5.39 E+00$ & & & $2.00 \mathrm{E}+05$ & & $9.07 E+04$ & \\
\hline 9 & $1.11 \mathrm{E}-01$ & & & $1.08 \mathrm{E}+05$ & & $9.09 \mathrm{E}+04$ & \\
\hline 10 & $3.78 \mathrm{E}+00$ & & & $1.08 \mathrm{E}+05$ & & $9.09 \mathrm{E}+04$ & \\
\hline 11 & $7.68 \mathrm{E}-01$ & $2.75 \mathrm{E}+01$ & $1.14 \mathrm{E}+04$ & $8.90 E+03$ & $1.38 \mathrm{E}+04$ & $1.00 \mathrm{E}+05$ & \\
\hline 12 & 8.23E-01 & $1.56 \mathrm{E}+01$ & $5.69 \mathrm{E}+04$ & $4.44 \mathrm{E}+04$ & $1.34 \mathrm{E}+05$ & $9.22 \mathrm{E}+04$ & \\
\hline 13 & $4.55 \mathrm{E}-02$ & $3.96 \mathrm{E}+01$ & $9.57 \mathrm{E}+04$ & $5.13 E+04$ & $1.73 E+05$ & $9.18 \mathrm{E}+04$ & \\
\hline 14 & $2.23 \mathrm{E}-01$ & $1.85 \mathrm{E}+02$ & $4.58 \mathrm{E}+05$ & $8.31 \mathrm{E}+04$ & $9.95 \mathrm{E}+05$ & $9.12 \mathrm{E}+04$ & \\
\hline 15 & $2.62 E+01$ & $8.40 \mathrm{E}-01$ & $1.05 \mathrm{E}+03$ & $9.52 \mathrm{E}+02$ & $2.07 \mathrm{E}+03$ & $8.68 \mathrm{E}+05$ & Not Bound by Cs-137 \\
\hline 17 & $5.71 E+03$ & & & $2.69 E+05$ & & $9.06 \mathrm{E}+04$ & \\
\hline 18 & $1.49 \mathrm{E}+00$ & & & $2.15 E+05$ & & $9.07 E+04$ & \\
\hline 19 & $3.53 \mathrm{E}+01$ & & & $3.96 \mathrm{E}+05$ & & $9.05 \mathrm{E}+04$ & \\
\hline 21 & $7.31 \mathrm{E}+01$ & $1.08 \mathrm{E}+01$ & $3.72 \mathrm{E}+03$ & $3.96 \mathrm{E}+03$ & $3.40 \mathrm{E}+03$ & $1.22 \mathrm{E}+05$ & Not Bound by Cs-137 \\
\hline 22 & $6.85 \mathrm{E}-01$ & $7.97 \mathrm{E}+00$ & $7.56 \mathrm{E}+03$ & $7.25 \mathrm{E}+03$ & $8.57 \mathrm{E}+03$ & $1.04 E+05$ & \\
\hline 26 & $1.24 \mathrm{E}-01$ & & & $3.96 \mathrm{E}+05$ & & $9.05 \mathrm{E}+04$ & \\
\hline 30 & $5.98 \mathrm{E}-02$ & & $1.31 \mathrm{E}+03$ & $1.08 \mathrm{E}+03$ & $1.32 \mathrm{E}+03$ & $6.09 \mathrm{E}+05$ & \\
\hline 32 & $1.47 \mathrm{E}-01$ & & $3.00 \mathrm{E}+03$ & $3.07 \mathrm{E}+03$ & $2.49 \mathrm{E}+03$ & $1.37 \mathrm{E}+05$ & \\
\hline 33 & $3.82 \mathrm{E}-01$ & & & $3.96 \mathrm{E}+05$ & & $9.05 \mathrm{E}+04$ & \\
\hline 34 & $3.23 \mathrm{E}-01$ & & & $3.06 \mathrm{E}+0 \mathrm{~S}$ & & $9.06 \mathrm{E}+04$ & \\
\hline 35 & $9.25 \mathrm{E}-02$ & & $4.29 \mathrm{E}+03$ & $3.62 \mathrm{E}+03$ & $2.71 \mathrm{E}+03$ & $1.28 \mathrm{E}+05$ & \\
\hline 36 & $1.84 \mathrm{E}-01$ & & $3.31 \mathrm{E}+03$ & $2.51 E+03$ & $1.75 \mathrm{E}+03$ & $1.60 \mathrm{E}+05$ & \\
\hline 39 & $1.65 \mathrm{E}-01$ & & $1.38 \mathrm{E}+03$ & $1.38 \mathrm{E}+03$ & $1.09 \mathrm{E}+03$ & $3.80 \mathrm{E}+05$ & \\
\hline 40 & $4.52 \mathrm{E}+00$ & $9.80 \mathrm{E}+02$ & $9.29 \mathrm{E}+05$ & $1.74 \mathrm{E}+0 \mathrm{~S}$ & $1.05 \mathrm{E}+06$ & $9.08 \mathrm{E}+04$ & \\
\hline 41 & $2.67 \mathrm{E}-01$ & & $1.22 \mathrm{E}+03$ & $1.55 E+03$ & $7.93 \mathrm{E}+02$ & $4.72 \mathrm{E}+05$ & \\
\hline 42 & $2.96 \mathrm{E}+00$ & $1.33 \mathrm{E}+02$ & $1.23 \mathrm{E}+05$ & $6.95 E+04$ & $1.72 \mathrm{E}+05$ & $9.14 \mathrm{E}+04$ & \\
\hline 43 & $5.10 \mathrm{E}-01$ & & $1.34 \mathrm{E}+03$ & $1.39 E+03$ & $1.08 \mathrm{E}+03$ & $3.80 \mathrm{E}+05$ & \\
\hline 47 & $1.93 \mathrm{E}-01$ & & & $3.52 \mathrm{E}+05$ & & $9.05 \mathrm{E}+04$ & \\
\hline 51 & $2.16 E+01$ & $2.60 \mathrm{E}+03$ & $1.39 \mathrm{E}+06$ & $1.87 \mathrm{E}+05$ & $1.36 \mathrm{E}+06$ & $9.07 \mathrm{E}+04$ & \\
\hline Minimum & & $8.40 \mathrm{E}-01$ & $1.05 \mathrm{E}+03$ & $9.52 \mathrm{E}+02$ & $7.93 \mathrm{E}+02$ & $9.05 E+04$ & \\
\hline Average & & $4.36 \mathrm{E}+02$ & $5.21 \mathrm{E}+05$ & $1.35 \mathrm{E}+05$ & $6.03 \mathrm{E}+05$ & $9.09 E+04$ & \\
\hline
\end{tabular}


Appendix 2

WSRC-TR-94 $\longdiv { 2 2 7 }$

Rev. 0

Page 12 of 16

Table 1. Plutonium Isotopic Waste Inventory

\begin{tabular}{|c|c|c|c|c|c|c|c|c|c|c|c|}
\hline & Total & & & & & & & & & & \\
\hline & Plutonium & Pu-238 & Pu-238 & Pu-239 & Pu-239 & Pu-240 & Pu-240 & Pu-241 & Pu-241 & Pu-242 & Pu-242 \\
\hline TANK\# & (g) & (g) & wt \% & (g) & wt \% & (g) & wt \% & (g) & wt \% & (g) & wt \% \\
\hline 1 & 2274 & 0 & 0.00 & 2139 & 94.08 & 130 & 5.74 & 3 & 0.12 & 2 & 0.07 \\
\hline 2 & 338 & 0 & 0.00 & 318 & 94.10 & 19 & 5.74 & 0 & 0.09 & \begin{tabular}{l|l}
0 \\
\end{tabular} & 0.07 \\
\hline 3 & 407 & 0 & 0.00 & 383 & 94.09 & 23 & 5.74 & 0 & 0.11 & \begin{tabular}{l|l}
0 \\
\end{tabular} & 0.07 \\
\hline 4 & 10228 & 0 & \begin{tabular}{l|l}
0.00 \\
\end{tabular} & 9616 & 94.02 & 586 & \begin{tabular}{l|l}
5.73 \\
\end{tabular} & 18 & \begin{tabular}{l|l}
0.18 \\
\end{tabular} & 7 & 0.07 \\
\hline 5 & 8282 & 0 & 0.00 & 7755 & 93.64 & 505 & 6.10 & 13 & 0.15 & 9 & 0.11 \\
\hline 6 & 4549 & 0 & 0.00 & 4095 & 90.03 & 388 & 8.53 & 16 & 0.35 & 46 & 1.00 \\
\hline 7 & 63001 & 0 & 0.00 & 58978 & 93.61 & 3842 & 6.10 & 102 & 0.16 & 74 & 0.12 \\
\hline 8 & 34156 & 0 & 0.00 & 31858 & 93.27 & 2046 & 5.99 & 85 & 0.25 & 166 & 0.49 \\
\hline 9 & 107 & 0 & 0.00 & 100 & 94.10 & 6 & 5.74 & 0 & 0.09 & 0 & 0.07 \\
\hline 10 & 54 & 0 & 0.00 & 51 & 94.10 & 3 & 5.74 & 0 & 0.09 & 0 & 0.07 \\
\hline 11 & 38947 & 9516 & 24.43 & 23942 & 61.47 & 4098 & 10.52 & 868 & 2.23 & 521 & 1.34 \\
\hline 12 & 52523 & 8632 & 16.44 & 37262 & 70.94 & 5617 & 10.69 & 527 & 1.00 & 484 & 0.92 \\
\hline 13 & 29635 & 3259 & 11.00 & 23452 & 79.14 & 2646 & 8.93 & 172 & 0.58 & 105 & 0.35 \\
\hline 14 & 1076 & 16 & 1.45 & 972 & 90.36 & 86 & 7.96 & 2 & 0.15 & 1 & 0.09 \\
\hline 15 & 26112 & 3621 & 13.87 & 19588 & 75.02 & 2588 & 9.91 & 199 & 0.76 & 117 & 0.45 \\
\hline 17 & 856 & 0 & 0.00 & 792 & 92.45 & 57 & 6.67 & 3 & 0.31 & 5 & 0.57 \\
\hline 18 & 1669 & 0 & 0.00 & 1550 & 92.84 & 108 & 6.44 & 4 & 0.27 & 7 & 0.45 \\
\hline 19 & 185 & 0 & 0.00 & 174 & 93.96 & 11 & 5.73 & 0 & 0.24 & 0 & 0.07 \\
\hline 21 & 80 & 59 & 73.92 & 18 & 22.01 & 3 & 3.48 & 0 & \begin{tabular}{l|l}
0.42 \\
\end{tabular} & 0 & 0.17 \\
\hline 22 & 101 & 101 & 100.00 & 0 & 0.00 & 0 & 0.00 & 0 & 0.00 & 0 & 0.00 \\
\hline 26 & 41072 & 0 & 0.00 & 38507 & 93.75 & 2347 & 5.72 & 189 & 0.46 & 29 & 0.07 \\
\hline 30 & 864 & 224 & 25.92 & 493 & 57.06 & 96 & 11.17 & 37 & 4.25 & 14 & 1.60 \\
\hline 32 & 98258 & 25575 & 26.03 & 56814 & 57.82 & 11504 & 11.71 & 2917 & 2.97 & 1448 & 1.47 \\
\hline 33 & 17716 & 0 & \begin{tabular}{l|l}
0.00 \\
\end{tabular} & 16612 & 93.77 & 1013 & 5.72 & 79 & 0.45 & 12 & 0.07 \\
\hline 34 & 22313 & 0 & 0.00 & 20924 & 93.78 & 1276 & 5.72 & 98 & 0.44 & 16 & 0.07 \\
\hline 35 & 94539 & 25866 & 27.36 & 52966 & 56.03 & 11051 & 11.69 & 3174 & 3.36 & 1481 & 1.57 \\
\hline 36 & 139 & 39 & 27.88 & 77 & 55.55 & 17 & 12.05 & 4 & 2.93 & 2 & 1.59 \\
\hline 39 & 139908 & 34102 & 2.37 & 82302 & 58.83 & 15593 & 11.15 & 5589 & 3.99 & 2322 & 1.66 \\
\hline 40 & 17325 & 135 & \begin{tabular}{l|l}
0.78 \\
\end{tabular} & 15960 & 92.12 & 1107 & 6.39 & 46 & 0.26 & 77 & 0.45 \\
\hline 41 & 13 & 13 & 100.00 & 0 & 0.00 & 0 & 0.00 & 0 & 0.00 & 0 & 0.00 \\
\hline 42 & 24957 & 2044 & 8.19 & 20631 & 82.66 & 2045 & 8.19 & 128 & 0.51 & 110 & 0.44 \\
\hline 43 & 3014 & 882 & 29.27 & 1696 & 56.29 & 306 & 10.15 & 96 & 3.20 & 33 & 1.09 \\
\hline 47 & 38819 & 0 & 0.00 & 36412 & 93.80 & 2220 & 5.72 & 160 & 0.41 & 27 & 0.07 \\
\hline 51 & 24786 & 156 & 0.63 & 22864 & 92.25 & 1589 & 6.41 & 66 & \begin{tabular}{l|}
0.27 \\
\end{tabular} & 111 & 0.45 \\
\hline Total Mass & 798302 & 114238 & & 589302 & & 72929 & & 14597 & & 7227 & \\
\hline \multicolumn{12}{|l|}{ Isotopics } \\
\hline Minimum & & & 0.00 & & 0.00 & & 0.00 & & 0.00 & & 0.00 \\
\hline Average & & & 14.31 & & 73.82 & & 9.14 & & 1.83 & & 0.91 \\
\hline Maximum & & & 100.00 & & 94.10 & & 12.05 & & 4.25 & & 1.66 \\
\hline
\end{tabular}


Rev. 0

\section{Appendix 2}

Page 13 of 16

Table 2. Comparison of Pu Limiting Volumes to Cs-137 Limiting Volumes

\begin{tabular}{|c|c|c|c|c|c|c|c|}
\hline & Volume of & Volume of & Volume of & Volume of & Volume of & Volume of & \\
\hline & Supernate & Supernate & Supernate & Supernate & Supernate & Supernate & \\
\hline & for Cs-137 & for $\mathrm{Pu}-238$ & for Pu-239 & for Pu-240 & for $\mathrm{Pu}-241$ & for $\mathrm{Pu}-242$ & \\
\hline & Limit & Limit & Limit & Limit & Limit & Limit & Tanks with Pu not \\
\hline TANK\# & (gallons) & (gallons) & (gallons) & (gallons) & (gallons) & (gallons) & bound by Cs-137 \\
\hline 1 & $4.13 \mathrm{E}-02$ & - & $2.45 E+02$ & $1.09 \mathrm{E}+03$ & $1.44 \mathrm{E}+03$ & $5.32 \mathrm{E}+06$ & \\
\hline 2 & $1.34 \mathrm{E}-01$ & - & $2.45 \mathrm{E}+02$ & $1.09 E+03$ & $1.89 \mathrm{E}+03$ & $5.32 \mathrm{E}+06$ & \\
\hline 3 & No sample & - & $2.45 \mathrm{E}+02$ & $1.09 \mathrm{E}+03$ & $1.57 \mathrm{E}+03$ & $5.32 \mathrm{E}+06$ & Not Bound by Cs-137 \\
\hline 4 & $6.97 \mathrm{E}-02$ & - & $2.45 \mathrm{E}+02$ & $1.10 \mathrm{E}+03$ & $9.37 \mathrm{E}+02$ & $5.33 \mathrm{E}+06$ & \\
\hline 5 & $1.94 \mathrm{E}-02$ & - & $2.46 \mathrm{E}+02$ & $1.03 \mathrm{E}+03$ & $1.11 \mathrm{E}+03$ & $3.49 \mathrm{E}+06$ & \\
\hline 6 & $1.11 E-01$ & - & $2.56 \mathrm{E}+02$ & $7.36 \mathrm{E}+02$ & $4.74 \mathrm{E}+02$ & $3.74 \mathrm{E}+05$ & \\
\hline 7 & $2.56 \mathrm{E}-01$ & - & $2.46 \mathrm{E}+02$ & $1.03 \mathrm{E}+03$ & $1.04 \mathrm{E}+03$ & $3.19 \mathrm{E}+06$ & \\
\hline 8 & $5.39 \mathrm{E}+00$ & - & $2.47 \mathrm{E}+02$ & $1.05 \mathrm{E}+03$ & $6.71 \mathrm{E}+02$ & $7.70 \mathrm{E}+05$ & \\
\hline 9 & $1.11 E-01$ & - & $2.45 \mathrm{E}+02$ & $1.09 \mathrm{E}+03$ & $1.91 \mathrm{E}+03$ & $5.32 \mathrm{E}+06$ & \\
\hline 10 & $3.78 \mathrm{E}+00$ & - & $2.45 \mathrm{E}+02$ & $1.09 \mathrm{E}+03$ & $1.78 \mathrm{E}+03$ & $5.32 \mathrm{E}+06$ & \\
\hline 11 & $7.68 \mathrm{E}-01$ & $3.42 \mathrm{E}+00$ & $3.75 \mathrm{E}+02$ & $5.97 \mathrm{E}+02$ & $7.53 \mathrm{E}+01$ & $2.80 \mathrm{E}+05$ & \\
\hline 12 & $8.23 E-01$ & $5.09 \mathrm{E}+00$ & $3.25 \mathrm{E}+02$ & $5.87 \mathrm{E}+02$ & $1.67 \mathrm{E}+02$ & $4.06 \mathrm{E}+05$ & \\
\hline 13 & $4.55 \mathrm{E}-02$ & $7.60 \mathrm{E}+00$ & $2.91 \mathrm{E}+02$ & $7.03 \mathrm{E}+02$ & $2.89 E+02$ & $1.06 \mathrm{E}+06$ & \\
\hline 14 & $2.23 \mathrm{E}-01$ & $5.77 \mathrm{E}+01$ & $2.55 \mathrm{E}+02$ & $7.89 \mathrm{E}+02$ & $1.13 \mathrm{E}+03$ & $4.31 \mathrm{E}+06$ & \\
\hline 15 & $2.62 \mathrm{E}+01$ & $6.03 E+00$ & $3.07 \mathrm{E}+02$ & $6.34 \mathrm{E}+02$ & $2.21 \mathrm{E}+02$ & $8.40 \mathrm{E}+05$ & Not Bound by Cs-137 \\
\hline 17 & $5.71 E+03$ & - & $2.49 \mathrm{E}+02$ & $9.42 \mathrm{E}+02$ & $5.51 \mathrm{E}+02$ & $6.55 \mathrm{E}+05$ & Not Bound by Cs-137 \\
\hline 18 & $1.49 \mathrm{E}+00$ & - & $2.48 E+02$ & $9.75 \mathrm{E}+02$ & $6.31 \mathrm{E}+02$ & $8.35 \mathrm{E}+05$ & \\
\hline 19 & $3.53 E+01$ & - & $2.45 E+02$ & $1.10 \mathrm{E}+03$ & $6.93 \mathrm{E}+02$ & $5.33 \mathrm{E}+06$ & \\
\hline 21 & $7.31 \mathrm{E}+01$ & $1.13 E+00$ & $1.05 \mathrm{E}+03$ & $1.81 \mathrm{E}+03$ & $3.98 \mathrm{E}+02$ & $2.15 \mathrm{E}+06$ & Not Bound by Cs-137 \\
\hline 22 & $6.85 \mathrm{E}-01$ & $8.36 \mathrm{E}-01$ & $\therefore$ & - & - & - & \\
\hline 26 & $1.24 \mathrm{E}-01$ & - & $2.46 \mathrm{E}+02$ & $1.10 \mathrm{E}+03$ & $3.65 \mathrm{E}+02$ & $5.34 \mathrm{E}+06$ & \\
\hline 30 & $5.98 \mathrm{E}-02$ & $3.22 \mathrm{E}+00$ & $4.04 \mathrm{E}+02$ & $5.62 \mathrm{E}+02$ & $3.95 E+01$ & $2.35 \mathrm{E}+05$ & \\
\hline 32 & $1.47 \mathrm{E}-01$ & $3.21 E+00$ & $3.98 \mathrm{E}+02$ & $5.36 \mathrm{E}+02$ & $5.66 \mathrm{E}+01$ & $2.54 \mathrm{E}+05$ & \\
\hline 33 & $3.82 \mathrm{E}-01$ & - & $2.46 \mathrm{E}+02$ & $1.10 \mathrm{E}+03$ & $3.76 \mathrm{E}+02$ & $5.34 \mathrm{E}+06$ & \\
\hline 34 & $3.23 \mathrm{E}-01$ & - & $2.46 \mathrm{E}+02$ & $1.10 \mathrm{E}+03$ & $3.84 E+02$ & $5.30 \mathrm{E}+06$ & \\
\hline 35 & $9.25 \mathrm{E}-02$ & $3.06 \mathrm{E}+00$ & $4.11 E+02$ & $5.37 \mathrm{E}+02$ & $5.00 \mathrm{E}+01$ & $2.39 \mathrm{E}+05$ & \\
\hline 36 & $1.84 \mathrm{E}-01$ & $3.00 \mathrm{E}+00$ & $4.14 \mathrm{E}+02$ & $5.21 \mathrm{E}+02$ & $5.73 E+01$ & $2.36 \mathrm{E}+05$ & \\
\hline 39 & $1.65 \mathrm{E}-01$ & $3.43 E+00$ & $3.91 \mathrm{E}+02$ & $5.63 \mathrm{E}+02$ & $4.20 \mathrm{E}+01$ & $2.26 \mathrm{E}+05$ & \\
\hline 40 & $4.52 E+00$ & $1.08 \mathrm{E}+02$ & $2.50 \mathrm{E}+02$ & $9.82 \mathrm{E}+02$ & $6.36 \mathrm{E}+02$ & $8.41 E+05$ & \\
\hline 41 & $2.67 \mathrm{E}-01$ & $8.36 \mathrm{E}-01$ & - & - & - & - & \\
\hline 42 & $2.96 \mathrm{E}+00$ & $1.02 \mathrm{E}+01$ & $2.79 \mathrm{E}+02$ & $7.66 \mathrm{E}+02$ & $3.28 \mathrm{E}+02$ & $8.48 E+05$ & \\
\hline 43 & $5.10 \mathrm{E}-01$ & $2.86 \mathrm{E}+00$ & $4.09 \mathrm{E}+02$ & $6.18 \mathrm{E}+02$ & $5.25 E+01$ & $3.42 \mathrm{E}+05$ & \\
\hline 47 & $1.93 \mathrm{E}-01$ & - & $2.45 E+02$ & $1.10 \mathrm{E}+03$ & $4.09 \mathrm{E}+02$ & $5.34 \mathrm{E}+06$ & \\
\hline 51 & $2.16 \mathrm{E}+01$ & $1.33 \mathrm{E}+02$ & $2.50 \mathrm{E}+02$ & $9.79 \mathrm{E}+02$ & $6.30 \mathrm{E}+02$ & $8.39 \mathrm{E}+05$ & \\
\hline Minimum & & $8.36 \mathrm{E}-01$ & $2.45 E+02$ & $5.21 \overline{E+02}$ & $3.95 E+01$ & $2.26 \mathrm{E}+05$ & \\
\hline Average & & $5.84 \mathrm{E}+00$ & $3.12 \mathrm{E}+02$ & $6.87 \mathrm{E}+02$ & $9.19 \mathrm{E}+01$ & $4.14 \mathrm{E}+0 \mathrm{~S}$ & \\
\hline
\end{tabular}


WSRC-TR-94 $\longdiv { 2 2 7 }$

Rev. 0

Appendix 3

Page 14 of 16

Table 1. Np-237 Masses with Volume of Supernate to Reach LAWV B-25 Limit

\begin{tabular}{|c|c|c|c|c|}
\hline & & & & Volume of \\
\hline & & Total & Calculated & Supernate \\
\hline & & Tank & $\mathrm{Np}-237$ & for $N p-237$ \\
\hline & Np-237 & Volume & Conc. & Limit \\
\hline TANK & (g) & (kgal) & $(\mathrm{mg} / \mathrm{l})$ & (gallons) \\
\hline 1 & $9.09 \mathrm{E}+02$ & $5.05 \mathrm{E}+02$ & $4.76 \mathrm{E}-01$ & $1.73 \mathrm{E}+01$ \\
\hline 2 & $3.00 \mathrm{E}+02$ & $5.40 \mathrm{E}+02$ & $1.47 \mathrm{E}-01$ & $5.61 E+01$ \\
\hline 3 & $5.36 \mathrm{E}+02$ & $5.40 \mathrm{E}+02$ & $2.62 \mathrm{E}-01$ & $3.14 \mathrm{E}+01$ \\
\hline 4 & $4.23 E+03$ & $5.21 \mathrm{E}+02$ & $2.15 \mathrm{E}+00$ & $3.84 \mathrm{E}+00$ \\
\hline 5 & $5.94 \mathrm{E}+03$ & $3.40 \mathrm{E}+01$ & $4.62 \mathrm{E}+01$ & $1.79 \mathrm{E}-01$ \\
\hline 6 & $1.22 \mathrm{E}+03$ & $2.50 \mathrm{E}+01$ & $1.29 \mathrm{E}+01$ & $6.37 \mathrm{E}-01$ \\
\hline 7 & $1.19 \mathrm{E}+04$ & $3.77 \mathrm{E}+02$ & $8.35 \mathrm{E}+00$ & $9.88 \mathrm{E}-01$ \\
\hline 8 & $4.47 \mathrm{E}+03$ & $1.64 \mathrm{E}+02$ & $7.19 \mathrm{E}+00$ & $1.15 \mathrm{E}+00$ \\
\hline 9 & $2.85 \mathrm{E}+02$ & $5.40 \mathrm{E}+02$ & $1.40 \mathrm{E}-01$ & $5.91 \mathrm{E}+01$ \\
\hline 10 & $6.18 \mathrm{E}+01$ & $2.17 \mathrm{E}+02$ & $7.52 \mathrm{E}-02$ & $1.10 \mathrm{E}+02$ \\
\hline 11 & $1.57 \mathrm{E}+03$ & $4.03 E+02$ & $1.03 E+00$ & $8.01 E+00$ \\
\hline 12 & $1.13 E+04$ & $2.15 \mathrm{E}+02$ & $1.38 \mathrm{E}+01$ & $5.96 \mathrm{E}-01$ \\
\hline 13 & $2.09 E+04$ & $7.78 \mathrm{E}+02$ & $7.10 \mathrm{E}+00$ & $1.16 \mathrm{E}+00$ \\
\hline 14 & $7.77 \mathrm{E}+02$ & $1.83 \mathrm{E}+02$ & $1.12 \mathrm{E}+00$ & $7.35 \mathrm{E}+00$ \\
\hline 15 & $5.04 \mathrm{E}+03$ & $3.12 \mathrm{E}+02$ & $4.27 \mathrm{E}+00$ & $1.93 \mathrm{E}+00$ \\
\hline 17 & $0.00 \mathrm{E}+00$ & & & \\
\hline 18 & $0.00 \mathrm{E}+00$ & & & \\
\hline 19 & $0.00 \mathrm{E}+00$ & & & \\
\hline 21 & $1.49 E+02$ & $1.23 E+02$ & $3.21 \mathrm{E}-01$ & $2.57 \mathrm{E}+01$ \\
\hline 22 & $3.33 \mathrm{E}+02$ & $1.64 E+02$ & $5.36 \mathrm{E}-01$ & $1.54 \mathrm{E}+01$ \\
\hline 26 & $0.00 \mathrm{E}+00$ & & & \\
\hline 30 & $1.17 \mathrm{E}+01$ & $1.24 E+03$ & $2.49 \mathrm{E}-03$ & $3.31 \mathrm{E}+03$ \\
\hline 32 & $1.63 \mathrm{E}+03$ & $1.23 \mathrm{E}+03$ & $3.49 \mathrm{E}-01$ & $2.36 \mathrm{E}+01$ \\
\hline 33 & $1.01 \mathrm{E}+04$ & $1.24 E+03$ & $2.16 \mathrm{E}+00$ & $3.83 \mathrm{E}+00$ \\
\hline 34 & $8.82 E+03$ & $1.21 E+03$ & $1.92 \mathrm{E}+00$ & $4.29 \mathrm{E}+00$ \\
\hline 35 & $1.39 \mathrm{E}+03$ & $1.26 \mathrm{E}+03$ & $2.93 \mathrm{E}-01$ & $2.81 \mathrm{E}+01$ \\
\hline 36 & $2.82 \mathrm{E}+00$ & $1.27 \mathrm{E}+03$ & $5.88 \mathrm{E}-04$ & $1.40 \mathrm{E}+04$ \\
\hline 39 & $1.95 \mathrm{E}+03$ & $1.01 \mathrm{E}+03$ & $5.12 \mathrm{E}-01$ & $1.61 \mathrm{E}+01$ \\
\hline 40 & $4.43 E+02$ & $4.33 \mathrm{E}+02$ & $2.70 \mathrm{E}-01$ & $3.05 \mathrm{E}+01$ \\
\hline 41 & $5.23 \mathrm{E}+01$ & $1.25 \mathrm{E}+03$ & $1.11 \mathrm{E}-02$ & $7.46 \mathrm{E}+02$ \\
\hline 42 & $3.23 \mathrm{E}+03$ & $3.22 \mathrm{E}+02$ & $2.65 \mathrm{E}+00$ & $3.11 E+00$ \\
\hline 43 & $1.51 \mathrm{E}+03$ & $7.17 \mathrm{E}+02$ & $5.58 \mathrm{E}-01$ & $1.48 \mathrm{E}+01$ \\
\hline 47 & $0.00 \mathrm{E}+00$ & & & \\
\hline 51 & $4.24 \mathrm{E}+02$ & $9.05 \mathrm{E}+02$ & $1.24 \mathrm{E}-01$ & $6.66 \mathrm{E}+01$ \\
\hline Total Mass & $9.95 \mathrm{E}+04$ & $1.77 \mathrm{E}+04$ & & \\
\hline Avg. Vol. & & & & $5.56 \mathrm{E}+00$ \\
\hline Min. Vol. & & & & $1.79 \mathrm{E}-01$ \\
\hline
\end{tabular}


Rev. 0

Appendix 3

Page 15 of 16

Table 2. Comparison of Np-237 Limiting Volumes to Cs-137 Limiting Volumes

\begin{tabular}{|c|c|c|c|}
\hline & Volume of & Volume of & \\
\hline & Supernate & Supernate & \\
\hline & for Cs-137 & for $\mathrm{Np}-237$ & \\
\hline & Limit & Limit & Tanks with Np-237 \\
\hline TANK \# & (gallons) & (gallons) & not bound by Cs-137 \\
\hline 1 & $4.13 \mathrm{E}-02$ & $1.73 \mathrm{E}+01$ & \\
\hline 2 & $1.34 \mathrm{E}-01$ & $5.61 E+01$ & \\
\hline 3 & No sample & $3.14 \mathrm{E}+01$ & Not Bound by Cs-137 \\
\hline 4 & $6.97 \mathrm{E}-02$ & $3.84 E+00$ & \\
\hline 5 & $1.94 \mathrm{E}-02$ & $1.79 \mathrm{E}-01$ & \\
\hline 6 & $1.11 \mathrm{E}-01$ & $6.37 \mathrm{E}-01$ & \\
\hline 7 & $2.56 \mathrm{E}-01$ & $9.88 \mathrm{E}-01$ & \\
\hline 8 & $5.39 \mathrm{E}+00$ & $1.15 E+00$ & Not Bound by Cs-137 \\
\hline 9 & $1.11 \mathrm{E}-01$ & $5.91 \mathrm{E}+01$ & \\
\hline 10 & $3.78 \mathrm{E}+00$ & $1.10 \mathrm{E}+02$ & \\
\hline 11 & $7.68 \mathrm{E}-01$ & $8.01 \mathrm{E}+00$ & \\
\hline 12 & $8.23 \mathrm{E}-01$ & $5.96 \mathrm{E}-01$ & Not Bound by Cs-137 \\
\hline 13 & $4.55 \mathrm{E}-02$ & $1.16 \mathrm{E}+00$ & $x$ \\
\hline 14 & $2.23 \mathrm{E}-01$ & $7.35 \mathrm{E}+00$ & \\
\hline 15 & $2.62 E+01$ & $1.93 \mathrm{E}+1 \mathrm{s0}$ & Not Bound by Cs-137 \\
\hline 17 & $5.71 \mathrm{E}+03$ & - & \\
\hline 18 & $1.49 \mathrm{E}+00$ & - & \\
\hline 19 & $3.53 \mathrm{E}+01$. & - & \\
\hline 21 & $7.31 E+01$ & $2.57 \mathrm{E}+01$ & Not Bound by Cs-137 \\
\hline 22 & $6.85 \mathrm{E}-01$ & $1.54 \mathrm{E}+01$ & \\
\hline 26 & $1.24 \mathrm{E}-01$ & - & \\
\hline 30 & $5.98 \mathrm{E}-02$ & $3.31 \mathrm{E}+03$ & \\
\hline 32 & $1.47 \mathrm{E}-01$ & $2.36 \mathrm{E}+01$ & \\
\hline 33 & $3.82 \mathrm{E}-01$ & $3.83 E+00$ & \\
\hline 34 & $3.23 \mathrm{E}-01$ & $4.29 \mathrm{E}+00$ & \\
\hline 35 & $9.25 \mathrm{E}-02$ & $2.81 \mathrm{E}+01$ & \\
\hline 36 & $1.84 \mathrm{E}-01$ & $1.40 \mathrm{E}+04$ & \\
\hline 39 & $1.65 \mathrm{E}-01$ & $1.61 \mathrm{E}+01$ & \\
\hline 40 & $4.52 \mathrm{E}+00$ & $3.05 \mathrm{E}+01$ & \\
\hline 41 & $2.67 \mathrm{E}-01$ & $7.46 \mathrm{E}+02$ & \\
\hline 42 & $2.96 \mathrm{E}+00$ & $3.11 \mathrm{E}+00$ & \\
\hline 43 & 5.10E-01 & $1.48 \mathrm{E}+01$ & \\
\hline 47 & $1.93 \mathrm{E}-01$ & - & \\
\hline 51 & $2.16 E+01$ & $6.66 \mathrm{E}+01$ & \\
\hline
\end{tabular}


WSRC-TR-94 227

Rev. 0

Appendix 4

Page 16 of 16

Table 1. Most Recent Sample Results For Cs-137 Concentrations

\begin{tabular}{|r|r|r|c|}
\hline & & & Volume of \\
\hline & & & Supernate \\
\hline & & \multicolumn{1}{|c|}{ Cs-137 } & for Cs-137 \\
\hline & Sample & \multicolumn{1}{c|}{ Conc. } & Limit \\
\hline TANK & \multicolumn{1}{|c|}{ Date } & \multicolumn{1}{c|}{ Ci/gal } & (gallons) \\
\hline 1 & $7 / 22 / 93$ & $1.84 \mathrm{E}+01$ & $4.13 \mathrm{E}-02$ \\
\hline 2 & $11 / 24 / 93$ & $5.69 \mathrm{E}+00$ & $1.34 \mathrm{E}-01$ \\
\hline 3 & No sample Data For Comparison \\
\hline 4 & $7 / 22 / 93$ & $1.09 \mathrm{E}+01$ & $6.97 \mathrm{E}-02$ \\
\hline 5 & $3 / 1 / 73$ & $3.92 \mathrm{E}+01$ & $1.94 \mathrm{E}-02$ \\
\hline 6 & $3 / 1 / 73$ & $6.82 \mathrm{E}+00$ & $1.11 \mathrm{E}-01$ \\
\hline 7 & $7 / 22 / 93$ & $2.97 \mathrm{E}+00$ & $2.56 \mathrm{E}-01$ \\
\hline 8 & $12 / 31 / 85$ & $1.41 \mathrm{E}-01$ & $5.39 \mathrm{E}+00$ \\
\hline 9 & $1 / 11 / 73$ & $6.82 \mathrm{E}+00$ & $1.11 \mathrm{E}-01$ \\
\hline 10 & $6 / 12 / 87$ & $2.01 \mathrm{E}-01$ & $3.78 \mathrm{E}+00$ \\
\hline 11 & $3 / 3 / 93$ & $9.89 \mathrm{E}-01$ & $7.68 \mathrm{E}-01$ \\
\hline 12 & $2 / 28 / 85$ & $9.24 \mathrm{E}-01$ & $8.23 \mathrm{E}-01$ \\
\hline 13 & $9 / 5 / 93$ & $1.67 \mathrm{E}+01$ & $4.55 \mathrm{E}-02$ \\
\hline 14 & $1 / 3 / 73$ & $3.41 \mathrm{E}+00$ & $2.23 \mathrm{E}-01$ \\
\hline 15 & $3 / 7 / 88$ & $2.90 \mathrm{E}-02$ & $2.62 \mathrm{E}+01$ \\
\hline 17 & $11 / 24 / 93$ & $1.33 \mathrm{E}-04$ & $5.71 \mathrm{E}+03$ \\
\hline 18 & $4 / 5 / 77$ & $5.11 \mathrm{E}-01$ & $1.49 \mathrm{E}+00$ \\
\hline 19 & $11 / 24 / 93$ & $2.15 \mathrm{E}-02$ & $3.53 \mathrm{E}+01$ \\
\hline 21 & $1 / 5 / 94$ & $1.04 \mathrm{E}-02$ & $7.31 \mathrm{E}+01$ \\
\hline 22 & $1 / 5 / 94$ & $1.11 \mathrm{E}+00$ & $6.85 \mathrm{E}-01$ \\
\hline 26 & $2 / 24 / 93$ & $6.15 \mathrm{E}+00$ & $1.24 \mathrm{E}-01$ \\
\hline 30 & $9 / 5 / 93$ & $1.27 \mathrm{E}+01$ & $5.98 \mathrm{E}-02$ \\
\hline 32 & $11 / 21 / 93$ & $5.18 \mathrm{E}+00$ & $1.47 \mathrm{E}-01$ \\
\hline 33 & $8 / 21 / 93$ & $1.99 \mathrm{E}+00$ & $3.82 \mathrm{E}-01$ \\
\hline 34 & $7 / 23 / 93$ & $2.35 \mathrm{E}+00$ & $3.23 \mathrm{E}-01$ \\
\hline 35 & $11 / 21 / 93$ & $8.22 \mathrm{E}+00$ & $9.25 \mathrm{E}-02$ \\
\hline 36 & $3 / 28 / 93$ & $4.14 \mathrm{E}+00$ & $1.84 \mathrm{E}-01$ \\
\hline 39 & $11 / 21 / 93$ & $4.60 \mathrm{E}+00$ & $1.65 \mathrm{E}-01$ \\
\hline 40 & $3 / 1 / 93$ & $1.68 \mathrm{E}-01$ & $4.52 \mathrm{E}+00$ \\
\hline 41 & $10 / 27 / 92$ & $2.85 \mathrm{E}+00$ & $2.67 \mathrm{E}-01$ \\
\hline 42 & $5 / 27 / 93$ & $2.57 \mathrm{E}-01$ & $2.96 \mathrm{E}+00$ \\
\hline 43 & $10 / 4 / 93$ & $1.49 \mathrm{E}+00$ & $5.10 \mathrm{E}-01$ \\
\hline 47 & $11 / 13 / 91$ & $3.94 \mathrm{E}+00$ & $1.93 \mathrm{E}-01$ \\
\hline 51 & $7 / 22 / 93$ & $3.52 \mathrm{E}-02$ & $2.16 \mathrm{E}+01$ \\
\hline & & & \\
\hline & & & \\
\hline & & &
\end{tabular}



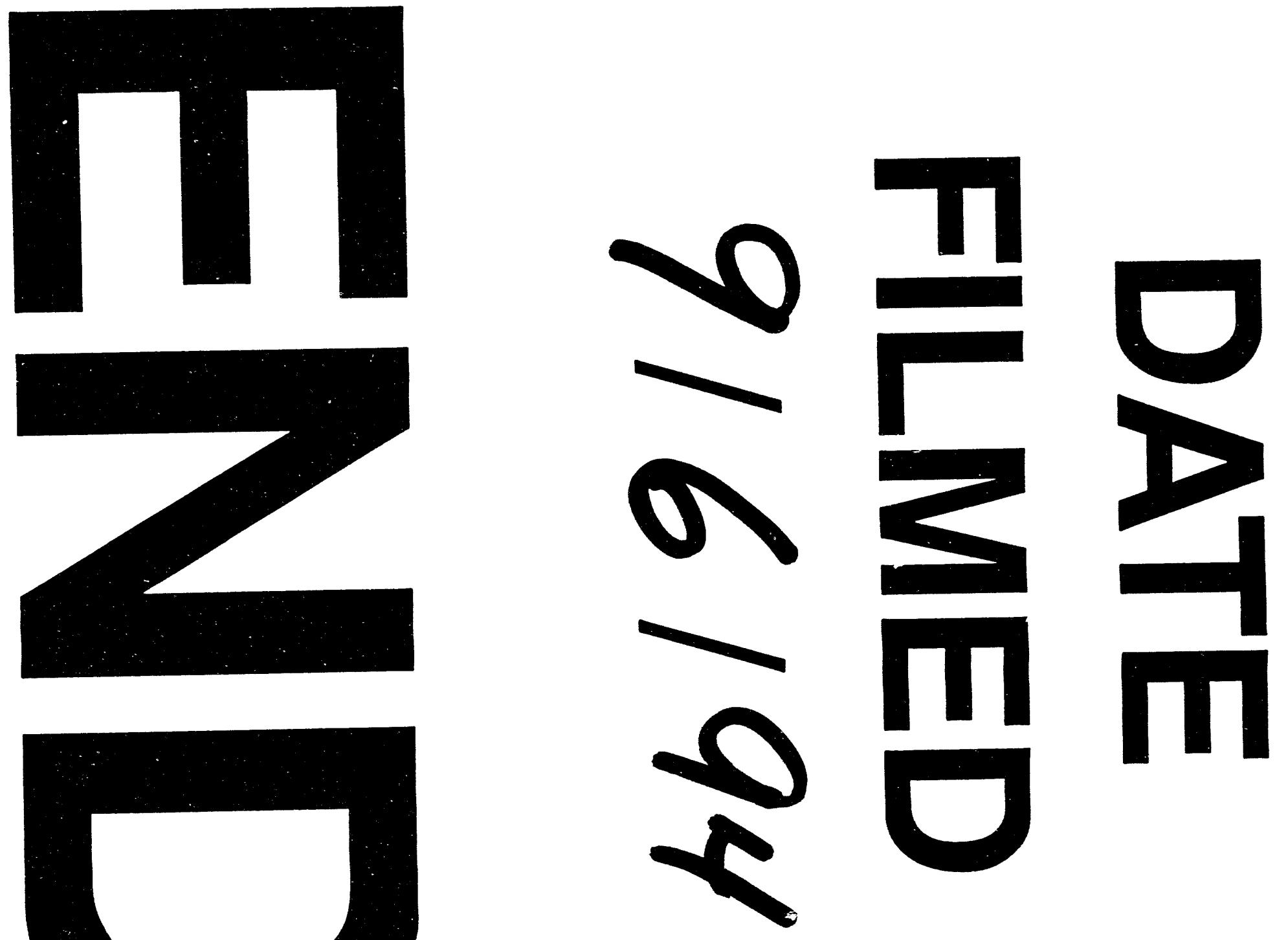
